\title{
The Impact of the Quality of Public Spending and Institutional Change on the Use of Oil Royalties: Exploring Public Management Research
}

\author{
CLAUDIA DA SILVA JORDÃO* \\ *Corvinus University of Budapest, Institute of Management; \\ claudia.jordao@stud.uni-corvinus.hu
}

DOI: $10.14267 / 978-963-503-867-1 \_11$

\begin{abstract}
The aim of the paper is to analyze the impacts of the quality of public spending and institutional change on the use of oil royalties. The related research is based on the (re)definition of concepts that are crucial for scholars in public administration. The debate on their utilization involves social and environmental issues, not limited to economic growth. Given the current economic crises faced by governments, there is a more significant limitation on public resources available by local governments. Therefore, one should not ignore the window of opportunity that has opened to give due attention to the quality of public spending. The research has also adopted the New Institutionalism theory that has as a premise that the institutions exert influence on the behavior of actors and on the political decisions. As a result, it is concluded that there is path dependence. The arguments of path dependence and increasing returns are used to explain the continuities. In the institutional analysis, the concept of path dependence helps to understand the possible behavior of economic agents. Thus, in this context, the economy does not represent an increase in the population's quality of life, and it is necessary to build a work methodology that involves the knowledge of local needs.
\end{abstract}

Keywords: quality of public spending, institutional change, oil royalties, public management

Funding: The present publication is the outcome of the project "From Talent to Young Researcher project aimed at activities supporting the research career model in higher education," identifier EFOP-3.6.3-VEKOP-16-2017-00007 co-supported by the European Union, Hungary, and the European Social Fund. 


\section{Introduction}

This paper deals with the study of oil royalties focusing on two central themes: the quality of public spending and institutional change. The theoretical contribution of the paper directly impacts the debate on the quality of public expenditure. It represents a significant portion of the budget utilization at any municipality. It is also important to highlight the negative impact that the mismanagement and improper use of this public money can make on the wellbeing of the population - especially of those who are the neediest of vital public services.

The concept of growth must also involve institutional change and local governance capacity. Evans (2003) points out that growth is centered on ideas and is the result of the actions of the anticipatory economic agents that respond to incentives. Thus, institutional arrangements begin to direct the incentives to develop ideas and become determinant for the rate of growth. This theory holds that basic institutions of governance are capable of playing a relevant role in generating development. However, the application of development planning must take into account the local culture, and the institutional change is based on local decision-making. Otherwise, imposing a planning model already pre-established without adaptation to reality, there is little possibility of success.

Regarding the use of oil royalties, Alves (2011) points out that there is a social purpose, and it is related to the idea of sustainable development, not limited to short and mediumterm objectives. According to Reis and Santana (2014), the reason for royalties is precisely to guarantee sustainable development, which would require that the resources from royalties be used in public investments aimed at the constitution of fixed assets and the formation of people. However, its use, although it has some legal provisions to guide spending actions, is not well defined - which gives greater freedom to local managers. In this way, the debate focused on the construction of the social purpose of royalties would then take place from a theoretical framework that encompassed the concepts of mineral income, cost of use, and intergenerational economic sustainability. 


\section{Theoretical background}

\section{Quality of public spending: a necessary conceptual definition}

What is public spending? Investment or costing? Investment is intended to expand future opportunities, but at the same time, investment also represents an outflow of money - an outflow of money to generate new inflows. Government spending comes from taxes that citizens pay. Public spending must be supported by law and must be budgetary. That is, it must have the legislative authority to carry out the expenditure. But public spending, in general, is not strictly government spending (based on budgetary decisions and bidding processes). In recent decades the definition of public spending has expanded and incorporated new relationships between government and private suppliers of public goods - such as, for example, partnerships between public and private (non-state expenditure, the one made for public purposes, but with private financing or partially private).

When can public spending be considered of high quality? As pointed out by Motta et al. (2014), there is still some difficulty in building a consensus on the strategies and measures necessary to implement the concept of quality of public spending. This concept, in turn, is relatively recent both in public bodies and in the academic field. Its conception involves the search for efficiency, effectiveness, and combating corruption. In a more normative view, the concept of quality of public spending has been used to charge governments for economic and social returns from the payment of taxes. An important fact for reflection is to consider its two general dimensions: one is its macroeconomic essence, which involves a strategic bias in the allocation of public resources and their impacts; the second dimension is microeconomic, which focuses on operational aspects of public spending.

Quality of public spending becomes a strategic instrument that enables the state to act in the economy and society, implementing public policies, focusing on fiscal balance. The way the state decides to implement its resources defines the means and priorities to meet social demands. Motta et al. (2014) highlight that government behavior will determine economic growth under the items of costing (government expenditure), capital formation (public investment), and income transfer policies. In some cases, depending on the government program, even in the items based on government funding, they can generate long-term impacts on the economic structure, both due to the accumulation of physical capital and investment. Thus, government action does not represent an increase only in costs but also in the accumulation of human capital and productivity. To allow for a better allocation of public resources, the legal support system (the concept of efficiency) and accounting (dimension of expenditure) need to be adjusted. 
As summarized by Pires (2009), the operational dimensions of the quality of public spending are efficiency, efficacy, effectiveness, transparency, and legality (verifiable, evaluable), ensuring economy, and legitimacy (partly embedded in legality). Sustainability is added, which argues that public spending should advance only to the extent that it can be sustained by levels of taxation and public debt.

\section{Institutions and institutional change}

From an institutionalist perspective, institutions are studied against the theoretical perspective of methodological individualism. From then on, habits and rules are considered. Some elements are considered, for example, 1) there is an emphasis on power relations and conflicts of interest; 2) the economy is no longer seen as self-regulated; 3) the historical process is seen as important for analysis; 4) the individual is not studied separately, but institutionalized. Institutions affect the performance of the economy and can form the incentive structure of individuals. For that, it is essential to give importance to culture, as it is precisely the informal limitations that can explain the path dependence - a term used when the behavior of the past influences the present, even if the current situation requires new responses.

Institutions are the rules of the game, and organizations are the players. The institutions have devised constraints that shape the way people evolve. It has the power to affect the performance of economies, and a differential performance is influenced by the way institutions evolve. They can, in turn, reduce uncertainty, define and limit the choices of individuals. Regardless of being formal or informal, institutions have many forms of constraints, namely formal rules or codes of behavior and conventions. That is, institutional constraints are the framework within which social interaction takes place, and this is the key to understanding historical change (North, 1990).

As mentioned above, the main purpose of the rules is to define the way of the game, create stability and reduce the costs of human interaction, but that does not mean that they are not changing. The institutional change is, most of the time, incremental, and together with the way by which the actors make choices account for path dependence. Institutional change is a complicated process because it may be related to several factors, such as rule changes or some informal constraints. As highlighted by North (1990), formal constraints are the results of political or judicial decisions, but informal constraints are much harder to detect. These cultural/informal constraints connect the past with the present and show up as an important key to explaining the path of historical change. 
Informal constraints come from socially transmitted information and are part of the heritage. That is, they can be transmitted by values and knowledge that influence the behavior, and there is the power of internally enforced codes of conduct that modify this behavior. The way how the mind processes information is the key to understand how the informal constraints influence the choice set. North (1990) explores the argument that incremental changes in such informal constraints will alter the game to increase or decrease cooperative outcomes. A transaction cost framework can be indirect evidence of changes in informal constraints and, hence, the transaction cost is a fertile field to explore informal constraints. In brief, the informal constraints (culture) play an important role in the incremental evolution, and hence this is the key to understanding this path dependence. And the tension between altered formal rules and the persisting informal construction produces outcomes that have important implications for the economies.

The arguments of path dependence and increasing returns are used to explain the continuities but also capable of providing plausible elements to explain the institutional change usually stemming from exogenous factors. The changes are never completely discontinuous, they are reconstructed containing previous elements, and even the informal constraints inserted in customs and traditions may remain. Thus, considering the historical analysis may allow elucidating the causal mechanisms that guide the process of ruptures and continuities, that is, the historical analysis that will allow to provide an analytical structure and to explain the relationship between choices, decision processes, institutional arrangements, and the political context. It is necessary to understand how the process of ideas dominates political discourse. In an institutional analysis, the concept of path dependence helps to understand the possible behavior of economic agents. The institutionalist theory considers that economic development is the result of institutions and institutional change, so for innovation to occur, institutional rearrangement is necessary. Technology is a variable resulting from the institutional environment, as technology is directly linked to a system of habits and knowledge shaped by values. Therefore, problem-solving is connected in the same institutional context (Arend et al., 2012). 


\section{Methodology}

As the aim is to analyze the impacts of two variables (quality of public spending and institutional change) on the use of oil royalties, this research focuses on creating some categories of analysis considered as key. As can be seen in the table below, concepts considered the most suitable, "questionable," and that should be avoided were selected to establish analysis criteria with a focus on the objective of the work. These concepts are associated with the quality of spending in the sense that some of them are in line, others are dubious, while the rest are in contrast with the quality of spending.

Table 1: Definition of categories

\section{$\begin{array}{ll}\text { Categories } & \text { Definition }\end{array}$}

Category 1: concept considered the most suitable for the use of public money from oil royaltiesapplications for sustainable development.

Category 2: Concept considered "questionable" for the use of public money from oil royalties.

Category 3: Concept should be avoided for the use of public money from oil royalties.
Type of expense directly related to the concept of sustainable development of the theoretical framework on the quality of public spending. According to Reis and Santana (2014), the proceeds from royalties should be used in public investments aimed at the constitution of fixed assets and the training of people. Adequate use in the formation of capital goods and human capital that follows the diversification of the economy in areas that can promote increased productivity and the average accumulation of capital with a view to economic growth.

Type of expense related to the concept above but not necessarily related to the social purpose of oil royalties. It includes the expenses to fund the maintenance of the activities of public administration bodies.

Type of expense that should be avoided, going to the opposite side of the concept about the good use of oil royalties. Considered as sensitive to corruption, as highlighted by Trevisan et al. (2014). It is included: publicity, events, and publication of official acts.

Source: own compilation 
These categories of analysis are intended to classify expenditures from oil royalties. Therefore, it is possible to analyze the local scenario in terms of whether there is a path dependence on the use of royalties or whether there are elements that classify an institutional change. The categories presented above aim to enable the construction of an overview of the differences regarding the application of the resources of royalties. With this, it aims to facilitate the analysis of its social purpose and the good use of public money.

\section{Results}

To exemplify the topic addressed and apply the analysis categories, data from Macaé City Hall in Rio de Janeiro State (Brazil) were selected. Macaé city is known internationally as the "oil capital" and, in recent years, the economy has grown by 600 percent. According to data from the Getulio Vargas Foundation, Macaé was considered the ninth-best Brazilian city to work in and one of the most dynamic in the country in 2008.

The data in Tables 2-5 represent the types of services managed by Macaé city, whose expenses represented more than 90 percent of the application of post-salt royalties between 2012 and 2014. (The largest oil reserves in Brazil and other countries are at depths ranging from 2000 to 3000 meters. This layer is called the post-salt layer as just below it can be found a geological layer formed by salt with a depth of 3000 to 5000 meters.)

Table 2: Applications considered the most suitable to contribute to sustainable development

\begin{tabular}{|c|c|c|c|c|c|}
\hline Services & 2012 & 2013 & 2014 & Total & Percentage \\
\hline University transport & $8.020 .393,65$ & $1.683 .152,41$ & $1.036 .986,25$ & $10.740 .532,31$ & $3,62 \%$ \\
\hline School feeding & 4.063.930,12 & $1.057 .543,89$ & $4.640 .485,22$ & $9.761 .959,23$ & $3,29 \%$ \\
\hline $\begin{array}{l}\text { Computer rental for } \\
\text { schools }\end{array}$ & 1.509.339,04 & - & - & $1.509 .339,04$ & $0,51 \%$ \\
\hline $\begin{array}{l}\text { Rental and maintenance of } \\
\text { tank trucks }\end{array}$ & - & - & $1.285 .368,87$ & $1.285 .368,87$ & $0,43 \%$ \\
\hline Macaé Digital & $1.152 .133,36$ & - & - & $1.152 .133,36$ & $0,39 \%$ \\
\hline Channel maintenance & - & - & $1.088 .373,70$ & $1.088 .373,70$ & $0,37 \%$ \\
\hline $\begin{array}{l}\text { Outsourcing of labor for } \\
\text { environmental services }\end{array}$ & - & $522.519,80$ & - & $522.519,80$ & $0,18 \%$ \\
\hline Total & & & & $26.060 .226,31$ & $8,79 \%$ \\
\hline
\end{tabular}

Source: Brazilian Transparency Portal (2015). 
Table 3: Applications considered "questionable" to contribute to sustainable development.

\begin{tabular}{|c|c|c|c|c|c|}
\hline Services & 2012 & 2013 & 2014 & Total & Percentage \\
\hline $\begin{array}{l}\text { Maintenance services, } \\
\text { urban and special cleaning, } \\
\text { sweeping and urban } \\
\text { cleaning, landfills, } \\
\text { recycling, aeration, vehicle } \\
\text { rental }\end{array}$ & $35.940 .673,84$ & $28.607 .960,64$ & $39.951 .839,41$ & $104.500 .473,89$ & $35,19 \%$ \\
\hline $\begin{array}{l}\text { Maintenance and } \\
\text { conservation of landfills, } \\
\text { public buildings, parks, } \\
\text { side roads and drainage } \\
\text { networks }\end{array}$ & $40.557 .298,46$ & $2.257 .106,84$ & $58.472 .557,75$ & $101.286 .963,05$ & $34,11 \%$ \\
\hline $\begin{array}{l}\text { Telephony for } \\
\text { administration }\end{array}$ & $894.879,57$ & 2.991.202,48 & $1.713 .892,65$ & $5.599 .974,70$ & $1,89 \%$ \\
\hline $\begin{array}{l}\text { Maintenance of public } \\
\text { buildings for events }\end{array}$ & $5.397 .737,64$ & - & - & $5.397 .737,64$ & $1,82 \%$ \\
\hline $\begin{array}{l}\text { Outsourcing of labor for } \\
\text { administration }\end{array}$ & $1.700 .586,53$ & $2.325 .831,14$ & $47.600,00$ & $4.074 .017,67$ & $1,37 \%$ \\
\hline $\begin{array}{l}\text { Transport to } \\
\text { administrative bodies }\end{array}$ & - & $477.000,00$ & $1.716 .527,06$ & $2.193 .527,06$ & $0,74 \%$ \\
\hline $\begin{array}{l}\text { Re-registration of urban } \\
\text { areas }\end{array}$ & $2.100 .794,64$ & - & - & $2.100 .794,64$ & $0,71 \%$ \\
\hline $\begin{array}{l}\text { Public lighting system } \\
\text { management }\end{array}$ & $1.881 .786,16$ & - & - & $1.881 .786,16$ & $0,63 \%$ \\
\hline Public cleaning & $1.495 .296,50$ & $78.639,05$ & $7.726,00$ & $1.581 .661,55$ & $0,53 \%$ \\
\hline $\begin{array}{l}\text { Development of tax } \\
\text { management system }\end{array}$ & $660.000,00$ & - & $694.062,68$ & $1.354 .062,68$ & $0,46 \%$ \\
\hline $\begin{array}{l}\text { Acquisition of computers } \\
\text { for administration }\end{array}$ & - & $192.260,20$ & - & $192.260,20$ & $0,06 \%$ \\
\hline Total & & & & $230.163 .259,24$ & $77,51 \%$ \\
\hline
\end{tabular}

Source: Brazilian Transparency Portal (2015). 
Table 4: Applications that should be avoided to contribute to sustainable development.

\begin{tabular}{lccccc}
\hline \multicolumn{1}{c}{ Services } & 2012 & 2013 & 2014 & Total & Percentage \\
\hline Government advertising & $14.784 .217,02$ & $9.594 .722,25$ & $6.284 .164,00$ & $30.663 .103,27$ & $10,33 \%$ \\
Event preparation & - & $1.258 .635,19$ & $3.517 .748,00$ & $4.776 .383,19$ & $1,61 \%$ \\
Publication of official acts & $3.278 .169,75$ & $665.490,24$ & - & $3.943 .659,99$ & $1,33 \%$ \\
$\begin{array}{l}\text { Air tickets, transfers, and } \\
\text { accommodation for the }\end{array}$ & $1.360 .989,88$ & - & - & & $1.360 .989,88$ \\
administration & & & & & $0,46 \%$ \\
Total & & & & $40.744 .136,33$ & $13,73 \%$ \\
\hline
\end{tabular}

Source: Brazilian Transparency Portal (2015).

Table 5: The percentage of each category for comparison

\begin{tabular}{lc}
\hline \multicolumn{1}{c}{ Category } & Percentage \\
\hline $\begin{array}{l}\text { Category 1: Applications are considered the most suitable to contribute to } \\
\text { sustainable development. }\end{array}$ & $8,8 \%$ \\
$\begin{array}{l}\text { Category 2: Applications considered "questionable" to contribute to sustainable } \\
\text { development. }\end{array}$ & $77,5 \%$ \\
$\begin{array}{l}\text { Category 3: Applications that should be avoided to contribute to sustainable } \\
\text { development. }\end{array}$ & $13,7 \%$ \\
\hline
\end{tabular}

Source: own compilation

Based on the results obtained, reference tables were elaborated above. Thus, the data indicate that Macaé city, between 2012 and 2014, invested a large part of the resources of post-salt royalties in current expenses that, as defined, are not linked to the formation or acquisition of capital goods to contribute to sustainable development. Through the highlighted tables, the observations indicate that the smallest part of the application of the resources of royalties ( 8.8 percent) fits into the related category more adequately to sustainable development. 77.5 percent of applications, on the other hand, fall into the category that has the potential to contribute to sustainable development, but not necessarily directly. Finally, 13.7 percent of personal applications are related to achievements not linked to the promotion of sustainable development and, therefore, have not been financed from royalties. 
As the studies by Oliveira Junior et al. (2020) point out, Macáe city has the potential to contribute to sustainable development, but without being directly related to its social purpose. But even so, Macaé city brings indicators that there is a need for a greater debate on the need to give the application of royalties a programmatic character, which leads its use to social purposes so that there can be a good use of public spending.

\section{Conclusions}

Actually, why in many local institutions does the misuse of public money still persist? Higher performance to generate quality public spending needs institutional change. This is because changing habits and interests - informal limitations, as mentioned earlier - is really difficult. This makes institutions dependent on their trajectories, and there is no point in simply copying the techniques of other successful institutions because the nature of learning is local and particular. Economic development is the result of the interaction between economics, politics, and culture, and there is a need for cooperation between the agents of the same institutional arrangement (Arendet et al. 2012). Once the oil reserves are exhausted and adding the fact that the environmental deficit generated by oil extraction, the scenario will become different and the local government will be dependent on the old scenario, that is, without new ways to diversify the economy and be independent of oil. Exactly, for this reason, the social purpose of royalties would be intended to enable sustainable development and generate an alternative for new paths. 


\section{References}

Alves, V. R. (2011). Aplicação dos royalties de petróleo e a garantia constitucional do desenvolvimento sustentável. (Dissertação de Mestrado). Universidade Federal do Rio Grande do Norte, Natal.

Arend, M., Cario, S., \& Enderle, R. (2012). Instituições, inovações e desenvolvimento econômico. Revista Pesquisa e Debate, SP, 23(1), 110-133.

Evans, P. (2003). Beyond "Institutional Monocropping": institutions, capabilities, and deliberative development. Sociologias [online], (9), 20-63.

Macaé. (2015). Despesas por Fonte de Recursos. Accessed on 21 de jul. de 2015, available on the Macaé Transparencies Portal: http://sistemas.macae.rj.gov.br/transparencia/index.asp?acao $=3 \&$ item $=6$

North, Douglass C. 1990. Institutions, Institutional Change, and Economic Performance. Cambridge: Cambridge University Press.

Oliveira Junior, T. M., Jordão, C., \& Braga, M. V. (2020). Para que serviram os royalties? Um debate sobre a aplicação da compensação financeira decorrente da exploração de petróleo e gás no município de Macaé. Revista Estudos de Administração e Sociedade, 5(1), 5268.

Pires, V. (2009). Gestão orçamentária e qualidade do gasto público. In Bizelli, José Luís \& Ferreira, Darlene. Governança pública e novos arranjos de gestão. Piracicaba: Jacintha Editores, pp. 55-78.

Reis, D. and Santana, J. 2015. Os efeitos da aplicação dos royalties petrolíferos sobre os investimento públicos nos municípios brasileiros. Revista da Administração Pública, Rio de Janeiro, 49(1), 91-117.

Trevisan, A., Chizzotti, A., Ianhez, J. A., Chizzotti, J., \& Verillo, J. (2004). O Combate à Corrupção nas Prefeituras do Brasil. Cotia: Ateliê Editorial. 